Canadian Journal of Fisheries and Aquatic Sciences

Canadian

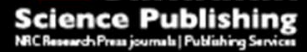

Journal canadien des sciences halieutiques et aquatiques

\title{
Sea Lamprey Carcasses Exert Local and Variable Food Web Effects in a Nutrient-limited Atlantic Coastal Stream
}

\begin{tabular}{|r|l|}
\hline Journal: & Canadian Journal of Fisheries and Aquatic Sciences \\
\hline Manuscript ID & Cjfas-2015-0506.R2 \\
\hline Manuscript Type: & Article \\
\hline Date Submitted by the Author: & 10 -May-2016 \\
\hline Complete List of Authors: & $\begin{array}{l}\text { Weaver, Daniel; University of Maine, Wildlife, Fisheries, and Conservation } \\
\text { Biology } \\
\text { Coghlan, Stephen; University of Maine, Wildlife, Fisheries, and } \\
\text { Conservation Biology } \\
\text { Zydlewski, Joseph; Maine Cooperative Fish and Wildlife Research Unit, }\end{array}$ \\
\hline Keyword: & $\begin{array}{l}\text { FRESHWATER < Environment/Habitat, RIVERS < Environment/Habitat, } \\
\text { PRODUCTIVITY < General, NUTRIENT DYNAMICS < General, } \\
\text { ANADROMOUS SPECIES < Organisms }\end{array}$ \\
\hline
\end{tabular}

\section{SCHOLARONE"}

Manuscripts 
1 This draft manuscript is distributed solely for purposes of scientific peer review. Its content is deliberative

2 and predecisional, so it must not be disclosed or released by reviewers. Because the manuscript has not

3 yet been approved for publication by the U.S. Geological Survey (USGS), it does not represent any official

$4 \quad$ USGS finding or policy.

5

6 Sea Lamprey Carcasses Exert Local and Variable Food Web Effects in a Nutrient-limited

$7 \quad$ Atlantic Coastal Stream.

8

9 Daniel M. Weaver

10 Department of Wildlife, Fisheries, and Conservation Biology

115755 Nutting Hall, University of Maine, Orono, Maine 04469, USA

12 daniel.weaver@maine.edu(703) 5953644

13

14 Stephen M. Coghlan Jr.

15 Department of Wildlife, Fisheries, and Conservation Biology

165755 Nutting Hall, University of Maine, Orono, Maine 04469, USA

17

18 Joseph Zydlewski

19 U.S. Geological Survey, Maine Cooperative Fish and Wildlife Research Unit and

20 Department of Wildlife, Fisheries, and Conservation Biology

215755 Nutting Hall, University of Maine, Orono, Maine 04469, USA 


\section{Abstract}

23 Resource flows from adjacent ecosystems are critical in maintaining structure and function of

24 freshwater food webs. Migrating sea lamprey Petromyzon marinus deliver a pulsed marine-

25 derived nutrient subsidy to rivers in spring when the metabolic demand of producers and

26 consumers are increasing. However, the spatial and temporal dynamics of these nutrient

27 subsidies are not well characterized. We used sea lamprey carcass additions in a small stream to examine changes in nutrients, primary productivity, and nutrient assimilation among consumers.

29 Algal biomass increased 57-71\% immediately adjacent to carcasses, however broader spatial 30 changes from multiple-site carcass addition may have been influenced by canopy cover. We

31 detected assimilation of nutrients (via $\delta^{13} \mathrm{C}$ and $\delta^{15} \mathrm{~N}$ ) among several macroinvertebrate families

32 including Heptageniidae, Hydropsychidae, and Perlidae. Our research suggests that subsidies

33 may evoke localized patch-scale effects on food webs, and the pathways of assimilation in

34 streams are likely coupled to adjacent terrestrial systems. This research underscores the

35 importance of connectivity in streams, which may influence sea lamprey spawning and elicit

36 varying food web responses from carcass subsidies due to fine scale habitat variables.

37 Key words: Petromyzon marinus; sea lamprey; nutrient dynamics; marine-derived nutrient

38 subsidies; streams; food webs 


\section{Introduction}

Energy and nutrient flows across ecosystem boundaries can influence the structure and

41 function of recipient ecosystems, alleviate nutrient limitation, and increase primary and

42 secondary productivity (Vanni 2002; Polis et al. 2004; Lamberti et al. 2010). In aquatic systems, carbon, nitrogen, and phosphorus (an important subset of potential nutrient subsidies), may

44 alleviate bottom-up constraints on productivity by facilitating in-stream production, and/or alter top-down effects if received directly by consumers (Rosemond et al. 1993; Lamberti 1996; resource availability and assimilation through both autotrophic and heterotrophic pathways.

The effect of nutrient subsidies varies with the magnitude and duration of the resource, as

49 well as the environmental and community-level processes of recipient systems (Marczak et al. 2007; Zhang and Richardson 2011). Pulsed nutrient subsidies may be sporadic or predictable,

51 large or small in magnitude, but are often short lived and may alleviate nutrient limitations and 52 stimulate productivity (Odum 1971; Yang et al. 2010; Weber and Brown 2013). Additionally,

53 habitat variables (i.e., temperature, substrate, flow) may fluctuate across spatial and temporal 54 scales influencing the effects of subsidies on food web structure (Roberts et al. 2007; Kohler et 55 al. 2012). Thus, the pathways by which nutrient subsidies are utilized are specific to the context 56 of the recipient ecosystem.

58 provide resource subsidies to ecosystems that support production of their offspring. Nutrients in 59 the form of excretion, gametes, and carcasses may influence recipient stream food webs through various pathways (Gende et al. 2002; Tiegs et al. 2011; Childress and McIntyre 2015). Subsidies

61 may be assimilated at the base of aquatic food webs in the form of inorganic nutrients, thereby 
62 increasing algal biomass and primary productivity (Claeson et al. 2006; Kohler et al. 2008), or

63 the production of heterotrophic microbes (Ruegg et al. 2011). Alternatively, subsidies may

64 enter food webs through direct consumption by consumers (e.g., macroinvertebrates and fish;

65 Lessard and Merritt 2006; Wipfli et al. 2003; Guyette et al. 2014); therefore nutrient response

66 pathways vary and may be further modified by stream characteristics.

67 In Atlantic coastal waters, sea lamprey Petromyzon marinus spawning migrations deliver

68 a pulse of marine-derived nutrient subsidies to freshwater streams and rivers in the spring. The

69 decay rates of sea lamprey carcasses and subsequent water enriching effects of nitrogen and

70 phosphorus occur over a relatively short period of several weeks (Weaver et al. 2015). At this

71 time rising water temperatures and increased photoperiod stimulates primary productivity and

72 increases the metabolic demand of consumers including young-of-the-year fish and

73 macroinvertebrates (Hall 1972; Gustafson-Greenwood and Moring 1990; Nislow and Kynard

74 2009). During this period of nutrient and energy limitation, nutrient subsidies from sea lamprey

75 received by Atlantic coastal waters are likely to be critical in maintaining structure and function

76 of stream food webs.

77 We sought to quantify the spatial and temporal dynamics of sea lamprey nutrient

78 subsidies on primary productivity and nutrient assimilation of stream organisms. We describe

79 and present the results of two studies, the first was a carcass addition experiment in 2013

80 designed to determine temporal changes in primary productivity, which helped inform the design

81 of a second experiment conducted in 2014 to investigate the spatial and temporal effects of

82 nutrient subsidies in more detail. To address our objective, we sought to quantify changes in (1)

83 stream nitrogen and phosphorus, (2) stream nutrient limitations, (3) spatial and temporal patterns 
84 of primary productivity attributed to sea lamprey carcass nutrients, and (4) the assimilation of 85 nutrients among select macroinvertebrates and juvenile sea lamprey (ammocoetes).

\section{Materials and Methods}

Study area

We conducted carcass addition experiments in 2013 and 2014 in Sedgeunkedunk Stream, $90 \mathrm{a} 3^{\text {rd }}$ order tributary flowing into the Penobscot River at river kilometer (rkm) 36.5 (Figure 1; A 91 and B). Two dams were removed on the stream, Mill Dam in 2008 and Meadow Dam in 2009, 92 restoring $5.3 \mathrm{~km}$ and connectivity to the ocean. In subsequent years, spawning sea lamprey were regularly observed during spring in Sedgeunkedunk Stream (Gardner et al. 2012; Hogg et al.

94 2013). However, we selected study reaches where we observed no sea lamprey, evidence of nest 95 building, or post-spawned carcasses during our experiments.

We collected pre-spawn sea lamprey for carcass addition experiments in 2013 from

97 Veazie Dam (rkm 45.0) and in 2014 from Milford Dam (rkm 61.0) on the main-stem Penobscot

River. Collection took place in May during migration, but before sea lamprey commenced nest

99 building and spawning activities. All collected fish were measured for mass $( \pm 0.1 \mathrm{~g})$ and total length $( \pm 1 \mathrm{~mm})$, then stored frozen at $-10{ }^{\circ} \mathrm{C}$ until experimental addition.

\section{Single Site Carcass Addition Experiment}

In 2013, we selected a 20-m reach comprising of two riffle-run sequences that were similar in stream and riparian habitat (Figure 1; A). Fifty carcasses were placed in mesh bags, and randomly assigned to one of three $2.5-\mathrm{cm}$ mesh metal cages (to discourage scavengers), and

106 staked in the mid channel of the stream. The average individual carcass mass was $0.758 \mathrm{~kg}( \pm$ 
$1070.023 \mathrm{SE}$ ); the total carcass mass added to the stream was $37.9 \mathrm{~kg}$. Carcasses were deployed on 10820 July, 2013.

\section{Multiple Site Carcass Addition Experiment}

Our results from 2013 directed our experimental design for 2014. In 2014 we chose a

112 reach upstream from the previous year (Figure 1; B). We delineated 10 sites along an

113 approximate $150 \mathrm{~m}$ reach (Figure 1; inset). Each site was comprised of a riffle and subsequent

114 run that ended at the beginning of the next riffle; the average length for each site was $12 \mathrm{~m}$. The

115 two uppermost sites (1 and 2) were designated as reference sites. The following six downstream

116 sites (3-8) were designated to receive 20 sea lamprey carcasses (120 carcasses total). Finally,

117 the two lowermost sites (9 and 10) received no carcasses. Carcasses were caged similar to

118 methods described above and were anchored at the upstream most end of each site. The average

119 individual mass among all carcasses was $0.767 \mathrm{~kg}( \pm 0.02 \mathrm{SE})$; the mass added to each site

120 averaged $15.3 \mathrm{~kg}( \pm 0.08 \mathrm{SE})$ and totaled $92.0 \mathrm{~kg}$ throughout the experimental reach. Carcasses

121 were deployed on 25 June, 2014.

122 The numbers of carcasses we added to Sedgeunkedunk Stream during each experiment

123 represent ecologically realistic densities that may be deposited after spring spawning. Mean

124 estimates of sea lamprey spawning run densities after dam removal in Sedgeunkedunk Stream

125 ranged 223-242 (47-51 fish/km; Hogg et al. 2013). Nislow and Kynard (2009) estimated 30-

$126136(100-453 \mathrm{fish} / \mathrm{km})$ spawning sea lamprey in a 300-m reach in Fort River, a tributary to the

127 Connecticut River, similar in width to Sedgeunkedunk Stream. Generally, however, population

128 estimates of spawning sea lamprey throughout the Northeastern United States are not well

129 characterized. 
130

131

132

133

134

135

136

137

138

139

140

141

142

143

144 $145 \mu \mathrm{g} \cdot \mathrm{L}^{-1}$ for total soluble phosphorus.

\section{Water chemistry}

During our multiple site carcass addition experiment (2014), we sampled stream water

for soluble nitrogen and phosphorus. Samples were taken $0.5 \mathrm{~m}$ from the right and left banks and the mid channel at each of the 10 sites prior to the addition of carcasses, then after $12 \mathrm{~h}$, days $1-4$, then every other day until day 14 . With the exception of our sample taken after $12 \mathrm{~h}$, all samples were collected during the same time of day. Approximately $60 \mathrm{~mL}$ of water was filtered through 25-mm, 0.45- $\mu \mathrm{m}$ mixed cellulose ester membranes (Millipore Corp., Billerica, Massachusetts, U.S.A.) with a syringe into an acid-washed bottle. Samples were stored frozen until analysis. Samples were analyzed for dissolved inorganic nitrogen as ammonium $\left(\mathrm{NH}_{4}{ }^{+}\right)$ and nitrate $\left(\mathrm{NO}_{3}{ }^{-}\right)$by flow injection analysis (O.I. ALPKEM Flow Solution FS3000, College Station, Texas, U.S.A.), and total soluble phosphorus by inductively coupled plasma optical emission spectrometry (Thermo iCAP 6000, Thermo Fisher Scientific, Marietta, OH, U.S.A) by the University of Maine Analytical Laboratory and Soil Testing Service. A filtered $60 \mathrm{~mL}$ sample of deionized water, serving as a blank, was run periodically among sets of samples.

Detection limits for ammonium and nitrate were 0.002 and $0.0005 \mathrm{mg} \cdot \mathrm{L}^{-1}$ respectively and 1.55

147 Primary productivity

We used nutrient diffusing substrates to quantify changes in algal biomass and 149 subsequent nutrient limitation (Tank and Dodds 2003; Tank et al. 2006). Our nutrient solution 150 treatments consisted of $0.5 \mathrm{M} \mathrm{NH}_{4} \mathrm{NO}_{3}, 0.25 \mathrm{M} \mathrm{KH}_{2} \mathrm{PO}_{4}, 0.5 \mathrm{M} \mathrm{NH}_{4} \mathrm{NO}_{3}+0.25 \mathrm{M} \mathrm{KH}_{2} \mathrm{PO}_{4}$, and a

151 control (hereafter referred to as $\mathrm{N}, \mathrm{P}, \mathrm{N}+\mathrm{P}$, and $\mathrm{C}$ respectively). Solutions were amended with $1522 \%$ agar and poured to the top of $60 \mathrm{~mL}$ polypropylene screw-cap bottles. The bottles were 
153 topped with $2.5 \mathrm{~cm}$ diameter, $0.7 \mu \mathrm{m}$ glass microfiber filters (GE Healthcare Life Sciences,

154 Pittsburgh, Pennsylvania, U.S.A.). We bore holes through the caps, which were fastened over 155 the filters, securing them flush against the nutrient augmented agar solution. We constructed arrays to house diffusers using 2.54-cm polyvinyl chloride (PVC) pipe to serve as a rectangular base with $3.8-\mathrm{cm}$ angled steel slats on top. Bottles were cable-tied to the slats. In 2013 we constructed arrays that contained nine replicates of each nutrient treatment for a total of 36 diffusers per array $(\mathrm{N}=72$ total diffusers). We deployed one array in the riffle downstream of the carcasses and the other array in the riffle upstream of the carcasses. In 2014 we constructed arrays containing 3 replicates of each nutrient treatment for a total of 12 diffusers per array. Three arrays were deployed at each site $(\mathrm{N}=360$ total diffusers). Arrays were deployed downstream of carcasses at each site but required a minimum depth of $18 \mathrm{~cm}$ to become fully submerged. All arrays remained submerged throughout both experiments. The downstream distance between the added carcasses and the arrays varied, but were approximately 166 1-2 m. We did not exclude grazing invertebrates from our nutrient diffusing substrate arrays 167 during both carcass addition experiments; however, similar to Tank and Dodds (2003), we did 168 not observe invertebrate colonization among the arrays. Replicates of each nutrient treatment within each array were sampled at one, two, and 170 three weeks after carcass addition as the majority of decomposition occurred during an initial 171 three week period (Weaver et al. 2015). Filters were lifted gently off the bottles with forceps, 172 placed into labeled $1.5 \mathrm{~mL}$ polyethylene tubes, and kept on ice in the dark. In the lab, filters 173 were stored at $-10{ }^{\circ} \mathrm{C}$ until extraction and analysis. Filters were homogenized using a $90 \%$ 174 acetone solution and a mortar and pestle. Extracted samples were analyzed for chlorophyll $a$, 175 corrected for pheophytin using spectrophotometry (Strickland and Parsons 1972; APHA 1999) 
176 with a Thermo Aquamate spectrophotometer (Thermo Fisher Scientific, Marietta, OH, U.S.A).

177 During both years we lost a few diffusing substrata replicates, particularly in 2014 during high

178 flows from a spate. We analyzed chlorophyll $a$ in 57 samples in 2013 and 311 samples in 2014.

179

180

181

182

183

184

185

186

187

188

189

190

191

192

193

194

195

196

197

198

Stream habitat variables

During both experiments, temperature loggers (Onset, Hobo Pendant UA-001-08, Cape Cod, Massachusetts, U.S.A) were placed in the stream reach and retrieved at the conclusion of the experiment. Loggers continuously recorded temperature at one-hour intervals. During the multiple site carcass addition experiment (2014) we measured stream habitat characteristics at each of the ten sites. We measured total stream depth and mean column velocity at $0.5-\mathrm{m}$ increments along one cross-sectional transect during base flow with a top-set wading rod and Swoffer model 2100 current velocity meter (Swoffer Instruments, Seattle, Washington, U.S.A). Percent overstory density was measured at each nutrient diffusing substrate array location with a spherical crown densiometer (model-A, Forestry Suppliers, Jackson, Mississippi, U.S.A), as described by Lemon (1956).

\section{Fish and Invertebrate Collection}

We caged individuals of a freshwater mussel, Eastern elliptio Elliptio complanata (Lightfoot 1786), and juvenile sea lamprey (ammocoetes) that we sampled before and after carcass addition for analysis of nitrogen $\left(\delta^{15} \mathrm{~N}\right)$ and carbon $\left(\delta^{13} \mathrm{C}\right)$ isotopes. Ammocoetes and Eastern elliptio were collected approximately $2 \mathrm{~km}$ downstream of our experimental reach. Fifty ammocoetes were collected with backpack electrofishing and kept in aerated buckets prior to caging. Fourty-two Eastern elliptio were collected by hand. We observed no mortality during 
199 sampling and transport, and all individuals appeared to recover after capture. Ammocoetes were 200 caged in a $0.25 \times 0.25 \mathrm{~m}$ crate lined with fine screened mesh filled with fine sand obtained from 201 adjacent areas in the stream. We observed ammocoetes bury immediately into the sediment 202 upon addition to each cage. The tops of each cage were left open and were positioned in the 203 stream so that the top was slightly above water. Eastern elliptio were placed into submerged $2040.25 \mathrm{~m}$ diameter circular mesh pens. Half of the individuals of each species were placed at site 2052 , one of the upstream reference sites, and the other half at site 9, downstream of all 120 206 carcasses (Figure 1). We nonselectively sampled ammocoetes prior to carcass addition, then 207 after three weeks. Eastern elliptio were nonselectively sampled prior to carcass addition, then 208 after three and seven weeks. Macroinvertebrate samples representing several functional feeding 209 groups were collected with a kicknet prior to carcass addition, and then after three and seven 210 weeks at sites 1, 5, and 10 (Figure 1). Functional groups included scrapers (Ephemeroptera:

211 Heptageniidae), predators (Megaloptera: Corydalidae; Plecoptera: Perlidae), and

212 collector/gatherers (Trichoptera: Philopotamidae, Hydropsychidae).

Samples of adult sea lamprey tissue were taken prior to carcass addition. After

214 euthanasia, a 1- $\mathrm{cm}^{2}$ section of muscle tissue was extracted from the left dorsolateral side of six 215 individuals. All macroinvertebrate and fish samples were stored at $-80^{\circ} \mathrm{C}$ until sample 216 preparation and stable isotope analysis.

Stable isotopes analysis

Stable isotope samples were prepared and analyzed at the University of New Brunswick

220 Stable Isotopes in Nature Laboratory. Whole bodies of insects and ammocoetes, and the soft 221 body component of Eastern elliptio extracted from the shell were used for analyses. 
222 Macroinvertebrate gut contents were not removed, therefore stable isotope values reflect the

223 whole body and food recently ingested. Samples were oven dried at $60^{\circ} \mathrm{C}$ for $24-48 \mathrm{~h}$, and then

224 ground into a fine powder with a mortar and pestle. Approximately $0.5 \mathrm{mg}$ of each

225 macroinvertebrate, mussel, and fish was weighed in tin capsules and combusted using a Costech

2264010 Elemental Analyzer. Measurements of $\delta^{13} \mathrm{C}$ and $\delta^{15} \mathrm{~N}$ were performed using a Delta XP

227 continuous flow isotope-ratio mass spectrometer (CF-IRMS; Thermo-Finnigan; Bremen,

228 Germany). Stable isotope values were expressed in parts per thousand or permil (\%o) and

229 calculated as: $\delta X=\left(\left[R_{\text {sample }} / R_{\text {standard }}\right]-1\right) \cdot 1000$, where $X$ is ${ }^{13} \mathrm{C}$ or ${ }^{15} \mathrm{~N}$, and $R$ is the ratio of the

230 heavy isotope to the light isotope $\left(R={ }^{13} \mathrm{C}:{ }^{12} \mathrm{C}\right.$ or ${ }^{15} \mathrm{~N}:{ }^{14} \mathrm{~N}$ sensu Jardine et al. 2003).

231 International standards were used to calculate $\mathrm{R}_{\text {standard }}$ values, which included Vienna Pee Dee

232 Belemnite for carbon and atmospheric air for nitrogen. Standard deviations of standard and

233 sample repeats were approximately $0.1 \%$ or less for $\delta^{13} \mathrm{C}$ and $\delta^{15} \mathrm{~N}$.

Statistical analysis

We analyzed changes in chlorophyll $a$ from the addition of sea lamprey nutrient subsidies

237 from the single site carcass addition experiment using multi-factor analysis of variance

238 (ANOVA). Residuals did not conform to a normal distribution (Shapiro-Wilk W test: $p<0.05$;

239 Zar 1999), therefore we applied a log transformation to chlorophyll $a$ values, which satisfied

240 normality assumptions. We modeled chlorophyll $a$ as a function of week, nutrient treatment, and

241 reach (treatment or reference) and all associated interactions. Furthermore, we determined

242 whether carcass subsidies significantly increased chlorophyll $a$ by modeling the chlorophyll $a$

243 values of the control nutrient diffusers as a function of week and reach. Main effects and

244 interactions were deemed significant at $p<0.05$. 
We analyzed changes in chlorophyll $a$ and stream water nutrient concentrations from the

246

247

248

249

250

251

252

253

254

255

256

257

258

multiple site carcass addition experiment using multi-factor ANOVA. For each time period (i.e. week for chlorophyll $a$; day for stream water nutrients), we averaged response values of the two reference sites $(1,2)$. We then subtracted mean reference values from each of the remaining downstream sites (3-10) for that particular time period. Residuals did not conform to a normal distribution (Shapiro-Wilk W test: $p<0.05$; Zar 1999). We added a constant integer to each value so that negative numbers (i.e., treatments that were lower on average than the mean reference) were above zero. The value of the constant integer was chosen so that the lowest value was raised slightly above zero. Then, a log transformation was applied to the mean adjusted response (i.e., chlorophyll $a$, or stream nutrient concentration), which satisfied normality assumptions. We modeled chlorophyll $a$ as a function of site, week, nutrient treatment, and the interaction of week and nutrient treatment. We modeled stream water nutrient concentrations as a function of site and day. Time was treated as a factor in both models. We conducted post-hoc pairwise tests for significant main effects.

We did not measure stream or terrestrial environmental variables continuously throughout the experiment, and could not include them in the multi-factor ANOVA models. We conducted a separate linear regression to analyze mean chlorophyll $a$ values for each diffuser array (averaged across nutrient treatment and time) as a function of site-specific local overstory density.

Finally, we tested for spatial autocorrelation for chlorophyll $a$ and stream nutrient concentrations among all treatment sites using a Mantel test. Two distance matrices were generated: one containing linear distances between each of the sites and another containing distances between our chlorophyll $a$ values or stream nutrient concentrations. The Mantel test 
268 computed the correlation of the two distance matrices, then calculated 1000 permutations to 269 generate a $p$-value; $p$-values less than 0.05 allowed us to reject the null hypothesis that the 270 spatial and response distances were unrelated (i.e., no autocorrelation).

271 We determined stream nutrient limitations during the single site and multiple site carcass

272 addition experiments from samples collected at the reference sites using a multi-factor ANOVA.

273 We modeled chlorophyll $a$ as a function of week and the addition of nitrogen, phosphorus,

274 nitrogen and phosphorus, or no nutrient addition (control). Significant main effects or

275 interactions $(p<0.05)$ allowed us to infer nutrient limitation or colimitation (Tank and Dodds

276 2003).

277

We analyzed mean stable isotope values $\left(\delta^{15} \mathrm{~N}\right.$ and $\left.\delta^{13} \mathrm{C}\right)$ with multivariate analysis of

278 variance (MANOVA) with the Pillai's trace test to test for spatial and temporal differences in

279 isotopic values among macroinvertebrate taxa, ammocoetes, and Eastern elliptio. We modeled

280 the isotope values as a function of stream location and week. Data were tested for multivariate

281 normality with Mardia's test (Mardia 1970), and for homogeneity of covariance matrices with a

282 Box M test. Among taxa, data were multivariate normal, but did not meet the equal covariance

283 assumption despite log transformation. The Pillai's trace test was selected because it is the most

284 robust multivariate analysis when the assumption of equal covariance (i.e., heteroscedasticity) is

285 not met (Johnson and Field 1993). Post-hoc multiple comparisons tests were conducted for those

286 taxa with significant stream location main effects $(p<0.05)$ to determine differences in isotopic

287 values between the reference site (Site 2) and two downstream treatment sites (Sites 5, and 9).

288 All analyses were performed with the statistical package RStudio, (Version 0.99.491).

\section{Results}


291

292

293

294

295

296

297

298

299

300

301

302

303

304

305

306

307

308

309

310

311

312

313

Single Site Carcass Addition Experiment

Mean daily stream temperatures were $22.5^{\circ} \mathrm{C}( \pm 0.25 \mathrm{SE})$ and ranged $20.0-26.6{ }^{\circ} \mathrm{C}$.

There were higher concentrations of chlorophyll $a$ among all nutrient treatments downstream of the carcasses compared to upstream ( $p<0.001$; Figure 2). Our multi-factor ANOVA found differences among nutrient treatment by week, indicating that the nutrient treatments were responding differently among each sampling period from the addition of sea lamprey carcasses $(p=0.038)$. This may be due to the $\mathrm{N}$ and $\mathrm{N}+\mathrm{P}$ treatments downstream of the carcasses, which exhibited a greater rate of change between the first and second weeks and second and third weeks compared to the rates of change upstream of the carcasses. Among control diffusers, our multi-factor ANOVA found chlorophyll $a$ concentrations were 57-71\% higher downstream of carcasses compared to the upstream reference over three weeks $(p<0.05$; Figure 2$)$.

\section{Multiple Site Carcass Addition Experiment}

The ten sites in our experimental reach were similar in physico-chemical stream habitat variables characteristic of a 3rd order stream (Table 1). However, forest overstory density varied among all ten sites. We estimated relatively higher overstory density among sites 3-6, and 9, and relatively lower overstory density among the other sites (Table 1). Our Mantel tests suggested spatial autocorrelation in that chlorophyll $a$, ammonium, and nitrate concentrations may have been influenced by adjacent sites $(p<0.05)$.

Daily stream temperature during the course of the experiment averaged $24.2{ }^{\circ} \mathrm{C}( \pm 0.42$ SE), and ranged 17.6-29.0 ${ }^{\circ} \mathrm{C}$. During the first week of our experiment, stream temperatures increased approximately $6{ }^{\circ} \mathrm{C}$. During the second week of our experiment, a spate, from hurricane Arthur passed through the watershed and our experimental reach. This reduced stream 
314 temperatures by an average of $8.0^{\circ} \mathrm{C}$, and increased mean stream velocities throughout the reach 315 from $0.18 \mathrm{~ms}^{-1}\left( \pm 0.02 \mathrm{SE}\right.$; baseflow) before the spate to $0.60 \mathrm{~ms}^{-1}( \pm 0.02 \mathrm{SE})$ after the spate.

316 Temperatures were relatively constant during the third week; however the stream remained

317 above base flow conditions for the remainder of the experiment.

We observed changes in stream nutrients during the course of our experiment. The multi-factor ANOVA identified differences in concentrations of all three nutrients across the sampling period $(p<0.001$; Figure 3$)$. We found differences in ammonium concentrations among sites $(p<0.001)$, but did not observe similar trends among nitrate or total soluble

322 phosphorus. Stream ammonium concentrations at sites downstream of the carcasses increased 323 from days 1-3 compared to the upstream reference sites (Figure 3; left panel). We selected days $324 \quad 2-4$ to depict nutrient patterns along all ten sites as during this time we expected carcasses to 325 liberate high concentrations of nutrients (Figure 3; right panel; Weaver et al. 2015). During days $326 \quad 2-4$ the concentrations of ammonium in stream water appear to increase linearly going

327 downstream, with the exception of site 8 . This trend becomes absent by day 8 as concentrations 328 appear similar among sites, coincidental with increased flows and runoff associated with the 329 spate. For comparison, we observed no directional trends in nitrate or total soluble phosphorus 330 concentrations during days $2-4$ (Figure 3 ). concentrations of the reference sites, while concentrations at sites 7-8 and 10 were higher than 333 the average of the reference sites (Figure 4). Results from our multi-factor ANOVA show 334 differences among all factors including site, week, nutrient treatment, and the interaction 335 between week and nutrient ( $p<0.05$; Figure 4$)$. The post-hoc test on the factor "site" revealed 336 sites 3-6, and 9 were different than sites 7, 8, and 10 for all weeks and nutrient treatments. In 
337 parallel with these trends, we found that sites 3-6, and 9 also had $20 \%$ higher overstory density

338 than the other sites (Table 1). Chlorophyll $a$ concentrations and percent overstory density among

339 the nutrient diffusing substrate arrays were functionally related $(p<0.05)$. Percent overstory

340 density explained $23 \%$ of the variation in chlorophyll $a$ concentrations, and generally we

341 observed lower concentrations at sites with higher overstory density (Table 1).

342 Our multi-factor ANOVA showed significant main effects of nitrogen and phosphorus on

343 chlorophyll $a$ in our reference sites for both carcass addition experiments $(p<0.05)$. These

344 results suggest nitrogen and phosphorus colimitation during our experiments (Tank and Dodds

345 2003). Generally, samples from the $\mathrm{N}+\mathrm{P}$ treatment had the highest chlorophyll $a$ concentrations

346 (Figure 2, 4).

Adult sea lamprey used in this experiment provided an enriched isotopic signal for ${ }^{15} \mathrm{~N}$

348 and ${ }^{13} \mathrm{C}\left(\right.$ mean $\left.\pm \mathrm{SE} ; \delta^{15} \mathrm{~N}=12.16 \pm 0.22 ; \delta^{13} \mathrm{C}=-17.96 \pm 0.19\right)$ relative to the freshwater

349 macroinvertebrates, ammocoetes, and Eastern elliptio sampled. We found that differences in

350 stable isotope values varied among taxa attributed to subsidies delivered by carcasses as well as

351 temporal changes in isotopic enrichment not related to the subsidies (Table 2; Figure 5). We

352 observed significant isotope enrichment, primarily $\delta{ }^{13} \mathrm{C}$, among sampled individuals of all

353 macroinvertebrate taxa over the three week period (Time main effect: $p<0.05$; Table 2).

354 Among Heptageniidae, Hydropsychidae, and Perlidae, we observed greater enrichment in stable

355 isotope values in the treatment sites relative to the reference site (Site main effect: $p<0.05$;

356 Table 2; Figure 5). There was a significant time by site interaction among Heptageniidae,

357 suggesting that the magnitude of the treatment effect changed over time. We observed

358 enrichment in ${ }^{13} \mathrm{C}$ among ammocoetes, however we found no differences among reference or 
359 treatment sites. Among Eastern elliptio, we observed depletion in both isotopes during the 360 course of the experiment.

\section{Discussion}

We sought to quantify the spatiotemporal effects of sea lamprey carcass subsidies in an Atlantic coastal stream food web. We observed immediate downstream increases in primary productivity from carcass subsidies. Over the addition of carcass subsidies at multiple sites we observed varying responses of stream nutrients and reduced or increased algal biomass compared to reference values. Overstory canopy density partially contributed to the patterns we observed.

368 The differences we found among sites may have reflected variability associated with other 369 environmental variables that we did not measure. We observed stable isotope enrichment 370 among a limited group of stream consumers but did not observe increased enrichment from 371 multiple-site carcass addition. Thus, nutrient subsidies from sea lamprey carcasses evoke largely 372 short-term localized effects limited to areas adjacent to the carcasses as demonstrated by Pacific 373 salmon (Claeson et al. 2006). Furthermore, we suggest that the pathways by which nutrients are 374 assimilated in food webs may be coupled to stream environmental variables, adjacent terrestrial 375 systems, and flow disturbances that may alter subsidy delivery and community structure (Fisher 376 et al. 1982; Power et al. 1988; Chaloner et al. 2004).

378 among chlorophyll $a$, ammonium, and nitrate concentrations. Sites that were closer to each other

379 had more similar concentrations that those farther apart. The presence of spatial autocorrelation may violate the assumption of independently and identically distributed residuals, which may

381 inflate the type I error rate, or the incorrect rejection of a true null hypothesis (Legendre 1993). 
382 Therefore we must use some caution when interpreting our ANOVA results. Our results suggest

383 that chlorophyll $a$ concentrations were, in part, driven by canopy cover. Thus, riparian

384 vegetation at one site may also have influenced an adjacent site. Among stream nutrient

385 concentrations we might expect spatial autocorrelation as only a small portion of nutrients

386 liberated from carcasses may be taken up and utilized by local stream organisms while the

387 remainder flows downstream.

The quantitative input of nutrient subsidies to recipient systems may not correspond to concurrent responses in consumer biomass. The spatial pattern of ammonium concentrations increased from upstream to downstream (Figure 3; right panel). However, the spatial pattern of delivered pulse of nutrient subsidies may initially stimulate consumer biomass in recipient systems. A larger pulse of subsidies, however, may not elicit correspondingly larger effects.

394 Consumer biomass may asymptote as organisms are constrained by assimilation efficiency, 395 limited by another nutrient or resource (e.g., phosphorus), or, as our results suggest, influenced by environmental variables and habitat heterogeneity.

We found primary productivity was co-limited by nitrogen and phosphorus in

398 Sedgeunkedunk Stream during both experiments. Other studies have generally concluded that

399 temperate Eastern streams are phosphorus limited (Peterson et al. 1983; Newbold et al. 1983;

400 Pringle and Bowers 1984), although see Norris (2012), while temperate Western streams are 401 nitrogen limited (Grimm and Fisher 1986; Hill and Knight 1988; Tank and Dodds 2003).

402 Productivity can vary across climatic and geologic regions (Minshall 1978), which may explain 403 nutrient limitations and the role that nutrient subsidies play in alleviating those limitations. The 404 stoichiometric ratios of nutrient subsidies (e.g., N:P) may elicit varying effects on the food webs 
405 of nutrient limited systems (Elser et al. 1996). Sea lamprey carcasses have N:P ratios that range 406 20:1-22:1 (Weaver et al. 2015). Therefore, sea lamprey carcass subsidies may serve to alleviate 407 nutrient limitations in Atlantic coastal streams during the spring. The pre-spawn carcasses we 408 used in our experiments likely contain more energy and nutrients (e.g., gametes) than post-spawn 409 carcasses as demonstrated with Pink salmon (Oncorhynchus gorbuscha; Gende et al. 2004).

410 Thus the pre-spawn carcasses we used may have amplified concentrations of dissolved nutrients 411 and corresponding effects on food webs. Disturbance can influence food web structure (Sousa 1984; Ledger et al. 2008). High 413 flows associated with a spate during 2014 may have influenced nutrient subsidy dynamics and 414 food webs. In 2014 we observed flows three times greater than base flow conditions and high 415 turbidity conditions associated with the spate. High flow disturbance events may have scoured 416 periphyton from our nutrient diffusing substrates, and reduced light availability to primary 417 producers through swifter turbid flowing waters, which likely suppressed algal biomass (Power 418 et al. 1988; Grimm and Fisher 1989; Hall et al. 2015). Furthermore, elevated stream flows likely 419 accelerated carcass breakdown and nutrient liberation to a time period shorter than a few weeks 420 (Weaver et al. 2015). Our carcasses were caged to discourage scavengers and promote retention 421 within the experimental reach rather than allow downstream displacement, which would likely 422 happen in a natural environment (Gende et al. 2004; Williams et al. 2010). Thus, high flow 423 disturbances may influence the balance between nutrient retention and transport; during high 424 flows, transport is favored (Meyer and Likens 1979; Doyle 2005; Hall et al. 2009). The patterns of algal biomass we observed may exemplify the coupled relationship of 426 streams and adjacent terrestrial systems. Sea lamprey migrate in the spring when tree canopies 427 have just begun to fill. These fish subsequently die in late spring and early summer when 
428 canopies are completely full. Primary producers face seasonal shifts in light and nutrient

429 limitations, while consumers face increased metabolic demands from rising water temperatures

430 (Hall 1972; Hill et al. 2001). Stream organisms may depend upon the seasonal arrival of these

431 nutrient subsidies. The temporal differences in executing our experiments (i.e., July 2013 versus

432 June 2014) may have resulted in disparate food web responses, however environmental

433 conditions such as temperature, canopy cover, and nutrient limitation were similar between

434 experiments.

435 Similar to other studies, we observed reduced primary productivity among sites with

436 relatively high percentages of overstory density (Lowe et al. 1986; Hill and Knight 1988; Table

437 1; Figure 4). The arrival of pulsed subsidies from sea lamprey may alleviate nutrient limitations

438 among primary producers thereby strengthening bottom-up effects (Lamberti 1996). Conversely,

439 areas imposed with light limitations may have lower primary production and consumers receive

440 the subsidy directly (Kiernan et al. 2010; Rosemond et al. 1993). Thus, nutrient subsidies may

441 influence stream food webs disparately and depend largely upon deterministic seasonal

442 processes, and environmental characteristics of streams and adjacent riparian habitats (Chaloner

443 et al. 2004).

444 We observed macroinvertebrates assimilate nutrients from sea lamprey carcasses, as

445 demonstrated similarly with Pacific salmon carcasses (Claeson et al. 2006), and carcass analogs

446 (Guyette et al. 2014). Nutrient subsidy assimilation among macroinvertebrates varied, likely due

447 to differences among the functional feeding groups (Cummins 1974). Perlidae and

448 Hydropsychidae, a predator and collector-gatherer respectively, may have fed directly on sea

449 lamprey tissue, while Heptageniidae, a scraper, may have assimilated nutrients from biofilms

450 enriched by nutrient subsidies. Sea lamprey nutrient subsidies may be important to heptageniid 
451 mayflies during increased photoperiod and rising temperatures, which facilitate algal growth.

452 Conversely, Lessard and Merritt (2006) found nutrient subsidies from fall spawning salmon did 453 not benefit heptageniid mayflies during periods of increased flows, and declining photoperiod 454 and temperature, which reduce algal growth. We observed no assimilation among Corydalidae 455 and Philopotamidae, a predator and collector-gatherer, respectively. Therefore the assimilation 456 of nutrient subsidies was not equivalent across the functional feeding groups. Furthermore, the 457 response of stream organisms to nutrient subsidies may need to be placed in the context of 458 subsidy arrival (i.e. fish phenology) and seasonally-variable environmental conditions. 459 Ammocoetes and Eastern elliptio are both filter feeders, and may assimilate nutrients 460 from decomposing sea lamprey carcass tissue as detritus. However, we detected no enrichment 461 in ammocoetes or Eastern elliptio attributed to carcass subsidies. Conversely Eastern elliptio 462 demonstrated isotope depletion during the experiment. We did not conduct preliminary 463 experiments to determine the effects of caging on these two species, therefore we cannot 464 conclude whether the cage affected their behavior or if these species do not utilize carcass 465 subsidies. Ammocoetes reside in silt beds and areas of slow-moving water within rivers and 466 streams adjacent to suitable adult spawning habitat (Potter 1980) and thus it is plausible that they 467 assimilate subsidies from adult carcasses or subsidy-enriched diatoms (Moore and Beamish 468 1973). In addition, ammocoetes reside in streams for up to eight years (Beamish 1980), and may 469 have multiple opportunities to assimilate carcass subsidies delivered to recipient streams 470 precluding assimilation by other freshwater consumers. Migrating fish serve as vectors of energy and nutrients among ecosystems. Many

472 populations have declined due to pervasive damming, habitat loss, and overfishing (Saunders et 473 al. 2006; Limburg and Waldman 2009; Hall et al. 2011) which have reduced the delivery of 
474 subsidies to resource limited ecosystems (Polis et al. 2004). Dam removal will facilitate

475 anadromous fish passage and restore linkages between marine and freshwater ecosystems (Hall

476 et al. 2011; Penobscot River Restoration Trust 2015). Our results suggest that nutrient subsidies

477 demonstrate local and variable responses that may be influenced by finer scale habitat variables.

478 The removal of barriers facilitates the movement of spawning adults into the upper reaches of

479 streams and watersheds (Gardner et al. 2012; Hogg et al. 2013). Therefore, carcass subsidies

480 may evoke varying effects on food webs influenced by local habitat and land-use characteristics.

Pulsed nutrient subsidies from anadromous sea lamprey may be important for Atlantic

482 coastal waters. The pathways by which subsidies are utilized may depend on the environmental

483 characteristics of the recipient system. We suggest that effects from sea lamprey nutrient

484 subsidies are relatively localized to areas adjacent to carcasses and further influenced by multiple

485 deterministic and stochastic mechanisms. Our research adds to a growing body of knowledge 486 that characterizes the fate and efficacy of cross-ecosystem subsidies.

487

\section{Acknowledgments}

489 We thank Lara Katz from the University of Maine for field assistance, Bill Halteman for 490 statistical guidance, and Rick Cunjak and Brian Hayden from the University of New Brunswick

491 Stable Isotopes in Nature Laboratory. Hamish Greig improved earlier versions of this

492 manuscript. Oliver Cox and Richard Dill from the Maine Department of Marine Resources

493 provided technical assistance in collecting sea lamprey. We thank the Town of Orrington, and

494 Bob’s Kozy Korner for land access. This work is based upon research supported in part by

495 Hatch grant \# ME0-8367-0H, National Oceanic and Atmospheric Administration, U.S.

496 Geological Survey Maine Cooperative Fish and Wildlife Research Unit, and the Department of 
497 Wildlife, Fisheries, and Conservation Biology and Maine Agriculture and Forest Experiment 498 Station Publication Number 3476, the University of Maine, Orono, Maine, USA. This research 499 was performed under University of Maine approved Institutional Animal Care and Use 500 Committee Protocol Number A2011-06-03. Any use of trade, firm, or product names is for 501 descriptive purposes only and does not imply endorsement by the U.S. Government. 
502

503

504

505

506

507

508

509

510

511

512

513

514

515

516

517

518

519

520

521

522

523

524

\section{References}

American Public Health Association, American Water Works Association, Water Environment Federation. 1999. Standard methods for the examination of water and wastewater. 20th ed. American Public Health Association, American Water Works Association, Water Environment Federation, Washington, D.C.

Beamish, F.W.H. 1980. Biology of the North American anadromous sea lamprey, Petromyzon marinus. Can. J. Fish. Aquat. Sci. 37(11): 1924-1943.

Chaloner, D.T., Lamberti, G.A., Merritt, R.W., Mitchell, N.L., Ostrom, P.H., and Wipfli, M.S. 2004. Variation in responses to spawning Pacific salmon among three south-eastern Alaska streams. Freshw. Biol. 49(5): 587-599.

Childress, E.S., and McIntyre, P.B. 2015. Multiple nutrient subsidy pathways from a spawning migration of iteroparous fish. Freshw. Biol. 60(3): 490-499.

Claeson, S.M., Li, J.L., Compton, J.E., and Bisson, P.A. 2006. Response of nutrients, biofilm, and benthic insects to salmon carcass addition. Can. J. Fish. Aquat. Sci. 63(6): 12301241.

Cummins, K.W. 1974. Structure and function of stream ecosystems. Bioscience 24(11): 631641.

Doyle, M.W. 2005. Incorporating hydrologic variability into nutrient spiraling. J. Geophys. Res. 110: G01003.

Elser, J.J., Dobberfuhl, D.R., MacKay, N.A., and Schampel, J.H. 1996. Organism size, life history, and N:P stoichiometry. Bioscience 46(9): 674-684.

Fisher, S.G., Gray, L.J., Grimm, N.B., and Busch, D.E. 1982. Temporal succession in a desert stream ecosystem following flash flooding. Ecol. Monogr. 52(1): 93-110. 
525 Gardner, C., Coghlan, S.M., and Zydlewski, J. 2012. Distribution and abundance of anadromous

526 sea lamprey spawners in a fragmented stream: current status and potential range

527 expansion following barrier removal. Northeastern Naturalist 19(1): 99-110.

528 Gende, S.M., Edwards, R.T., Willson, M.F., and Wipfli, M.S. 2002. Pacific salmon in aquatic $529 \quad$ and terrestrial ecosystems. Bioscience 52(10): 917-928.

530 Gende, S.M., Quinn, T.P., Willson, M.F., Heintz, R., and Scott, T.M. 2004. Magnitude and fate 531 of salmon-derived nutrients and energy in a coastal stream ecosystem. J. Freshwater Ecol. 19(1): 149-160.

Grimm, N.B., and Fisher, S.G. 1986. Nitrogen limitation in a Sonoran Desert stream. J. N. Am.

Grimm, N.B., and Fisher, S.G. 1989. Stability of periphyton and macroinvertebrates to disturbance by flash floods in a desert stream. J. N. Am. Benthol. Soc. 8(4): 293-307.

537 Gustafson-Greenwood, K.I. and Moring, J.R. 1990. Territory size and distribution of newly538 emerged Atlantic salmon (Salmo salar). Hydrobiologia 206(2): 125-131.

Guyette, M.Q., Loftin, C.S., Zydlewski, J., and Cunjak, R. 2014. Carcass analogues provide marine subsidies for macroinvertebrates and juvenile Atlantic salmon in temperate oligotrophic streams. Freshw. Biol. 59(2): 392-406.

Hall, C.A.S. 1972. Migration and metabolism in a temperate stream ecosystem. Ecology 53(4): $585-604$.

544 Hall, C.J., Jordaan, A., and Frisk, M.G. 2011. The historic influence of dams on diadromous fish 545 habitat with a focus on river herring and hydrologic longitudinal connectivity. Landscape 546 Ecology 26(1): 95-107. 
547 Hall, R.O., Baker, M.A., Arp, C.D., and Koch, B.J. 2009. Hydrologic control of nitrogen

548

549

550

551

552

553

554

555

556

557

558

559

560

561

562

563

564

565

566

567

568 removal, storage, and export in a mountain stream. Limnol. Oceanogr. 54(6): 2128-2142.

Hall, R.O., Yackulic, C.B., Kennedy, T.A., Yard, M.D., Rosi-Marshall, E.J., Voichick, N., and Behn, K.E. 2015. Turbidity, light, temperature, and hydropeaking control primary productivity in the Colorado River, Grand Canyon. Limnol. Oceanogr. 60(2): 512 -526.

Hill, W.R., and Knight, A.W. 1988. Nutrient and light limitation of algae in two Northern California streams. J. Phycol. 24(2): 125-132.

Hill, W.R., Mulholland, P.J., and Marzolf, E.R. 2001. Stream ecosystem responses to forest leaf emergence in spring. Ecology 82(8): 2306-2319.

Hogg, R., Coghlan, S.M., and Zydlewski, J. 2013. Anadromous sea lamprey recolonize a Maine coastal river tributary after dam removal. Trans. Am. Fish. Soc. 142(5): 1381-1394.

Jardine, T.D., McGeachy, S.A., Paton, C.M., Savoie, M., and Cunjak, R.A. 2003. Stable isotopes in aquatic systems: sample preparation, analysis, and interpretation. Can. Manuscr. Rep. Fish. Aquat. Sci. No. 2656: 39 p.

Johnson, C.R., and Field, C.A. 1993. Using fixed-effects model multivariate analysis of variance in marine biology and ecology. Oceanogr. Mar. Biol. Annu. Rev. 31: 177-221.

Kiernan, J.D., Harvey, B.N., and Johnson, M.L. 2010. Direct versus indirect pathways of salmon-derived nutrient incorporation in experimental lotic food webs. Can. J. Fish. Aquat. Sci. 67(12): 1909-1924.

Kohler, A.E., and Rugenski, A., and Taki, D. 2008. Stream food web response to a salmon carcass analog addition in two central Idaho, U.S.A. streams. Freshw. Biol. 53(3): 446460. 
569 Kohler, T.J., Heatherly, T.N., El-Sabaawi, R.W., Zandona, E., Marshall, M.C., Flecker, A.S.,

570 Pringle, C.M., Reznick, D.N., and Thomas, S.A. 2012. Flow, nutrients, and light

571 availability influence Neotropical epilithon biomass and stoichiometry. Freshwater

$572 \quad$ Science 31(4): 1019-1034.

573 Lamberti, G.A. 1996. The role of periphyton in benthic food webs. In Algal ecology: freshwater

574 benthic ecosystems. Edited by R.J. Stevenson, M.L. Bothwell, and R.L. Lowe. Academic 575 Press, San Diego, California. pp. 553-572.

576 Lamberti, G.A., Chaloner, D.T., and Hershey, A.E. 2010. Linkages among aquatic ecosystems. J.

577 N. Am. Benthol. Soc. 29(1): 245-263.

578 Ledger, M.E., Harris, R.M.L., Armitage, P.D., and Milner, A.M. 2008. Disturbance frequency

579 influences patch dynamics in stream benthic algal communities. Oecologia 155(4): 809$580 \quad 819$.

581 Legendre, P. 1993. Spatial autocorrelation: trouble or new paradigm? Ecology 74(6): 1659 5821673.

583 Lemon, P.E. 1956. A spherical densiometer for estimating forest overstory density. Forest

$584 \quad$ Science 2: 314-320.

585 Lessard, J.L., and Merritt, R.W. 2006. Influence of marine-derived nutrients from spawning 586 salmon on aquatic insect communities in southeast Alaskan streams. Oikos 113(2): 334 $587 \quad 343$.

588 Limburg, K.E., and Waldman, J.R. 2009. Dramatic declines in North Atlantic diadromous fishes. 589 Bioscience 59(11): 955-965. 
Lowe, R.L., Golladay, S.W., and Webster, J.R. 1986. Periphyton response to nutrient manipulation in streams draining clearcut and forested watersheds. J. N. Am. Benthol. Soc. 5(3): 221-229.

Marczak, L.B., Thompson, R.M., and Richardson, J.S. 2007. Meta-analysis: trophic level, habiat, and productivity shape the food web effects of resource subsidies. Ecology 88(1): 140148.

Mardia, K.V. 1970. Measures of multivariate skewness and kurtosis. Biometrika 57(3): 519-530.

Meyer, J.L., and Likens, G.E. 1979. Transport and transformation of phosphorus in a forest stream ecosystem. Ecology 60(6): 1255-1269.

Minshall, G.W. 1978. Autotrophy in stream ecosystems. Bioscience 28(12): 767-771.

Moore, J.W., and Beamish, F.W.H. 1973. Food of larval sea lamprey (Petromyzon marinus) and American brook lamprey (Lampetra lamottei). J. Fish. Res. Board Can. 30(1): 7-15.

Newbold, J.D., Elwood, J.W., O’Neill, R.V., and Sheldon, A.L. 1983. Phosphorus dynamics in a woodland stream ecosystem: a study of nutrient spiralling. Ecology 64(5): 1249-1265.

Nislow, K.H., and Kynard, B.E. 2009. The role of anadromous sea lamprey in nutrient and material transport between marine and freshwater environments. In Challenges for Diadromous Fishes in a Dynamic Global Environment. Edited by A. Haro, K.L. Smith, R.A. Rulifson, C.M. Moffitt, R.J. Klauda, M.J. Dadswell, R.A. Cunjak, J.E. Cooper, K.L. Beal, and T.S. Avery. American Fisheries Society, Bethesda, Maryland. pp. 485-494.

Norris, K.G. 2012. The influence of anadromous alewife on Maine lakes and streams: using nutrient limitation assays and stable isotopes to track marine-derived nutrients. M.Sc. thesis, Department of Ecology and Environmental Science, The University of Maine, Orono, Maine. 
613 Odum, H.T. 1971. Environment, Power, and Society. Wiley-Interscience, New York.

614 Penobscot River Restoration Trust, 2015. Home page of the Penobscot River Restoration Trust, 615 Available from http://www.penobscotriver.org/ [accessed 30 October 2015].

616 617 618 619 620 621 622 623 624 625 626 627 628 629 630 631 632 633 634 635

Peterson, B.J., Hobbie, J.E., and Corliss, T.L. 1983. A continuous-flow periphyton bioassay: tests of nutrient limitation in a tundra stream. Limnol. Oceanogr. 28(3): 583-591.

Polis, G.A., Power, M.E., and Huxel, G. 2004. Food webs at the landscape level. University of Chicago Press, Chicago, Illinois.

Potter, I.C. 1980. Ecology of larval and metamorphosing lampreys. Can. J. Fish. Aquat. Sci. 37(11): 1641-1657.

Power, M.E., Stout, R.J., Cushing, C.E., Harper, P.P., Hauer, F.R., Matthews, W.J., Moyle, P.B., Statzner, B., and Wais De Badgen, I.R. 1988. Biotic and abiotic controls in river and stream communities. J. N. Am. Benthol. Soc. 7(4): 456-479.

Pringle, C.M., and Bowers, J.A. 1984. An in situ substratum fertilization technique: diatom colonization on nutrient-enriched, sand substrata. Can. J. Fish. Aquat. Sci. 41(8): 12471251.

Roberts, B.J., Mulholland, P.J., and Hill, W.R. 2007. Multiple scales of temporal variability in ecosystem metabolism rates: results from 2 years of continuous monitoring in a forested headwater stream. Ecosystems 10(4): 588-606.

Rosemond, A.D., Mulholland, P.J., and Elwood, J.W. 1993. Top-down and bottom-up control of stream periphyton: effects of nutrients and herbivores. Ecology 74(4): 1264-1280.

Ruegg, J., S.D. Tiegs, D.T. Chaloner, P.S. Levi, J.L. Tank, and Lamberti, G.A. 2011. Salmon subsidies alleviate nutrient limitation of benthic biofilms in southeast Alaska stream. Canadian Journal of Fisheries and Aquatic Sciences 68(2): 277-287. 
636 Saunders, R., Hachey, M.A., and Fay, C.W. 2006. Maine's diadromous fish community: past, 637 present, and implications for Atlantic salmon recovery. Fisheries 31(11): 537-547.

638 639

640

641

642

643

644

645

646

647

648

649

650

651

652

653

654

655

656

Res. Board Can. No. 167.

Sousa, W.P. 1984. The role of disturbance in natural communities. Annu. Rev. Ecol. Syst. 15(1): 353-391.

Tank, J.L., and Dodds, W.K. 2003. Nutrient limitation of epilithic and epixylic biofilms in ten North American streams. Freshw. Biol. 48(6): 1031-1049.

Tank, J.L., Bernot, M.J., and Rosi-Marshall, E.J. 2006. Nitrogen limitation and uptake. In Methods in Stream Ecology. Edited by F.R. Hauer, and G.A. Lamberti. Academic Press, Burlington, Massachusetts. pp. 213-238.

Tiegs, S.D., Levi, P.S., Ruegg, J., Chaloner, D.T., Tank, J.L., and Lamberti, G.A. 2011. Ecological effects of live salmon exceed those of carcasses during an annual spawning migration. Ecosystems 14(4): 598-614.

Vanni, M.J. 2002. Nutrient cycling by animals in freshwater ecosystems. Annu. Rev. Ecol. Syst. 33: $341-370$.

Weaver, D.M., Coghlan, S.M. Jr., Zydlewski, J., Hogg, R.S., and Canton, M. 2015. Decomposition of sea lamprey Petromyzon marinus carcasses: temperature effects, nutrient dynamics, and implications for stream food webs. Hydrobiologia 760(1): 57-67.

Weber, M.J., and Brown, M.L. 2013. Continuous, pulsed and disrupted nutrient subsidy effects on ecosystem productivity, stability, and energy flow. Ecosphere 4(2): 27. 
657 Williams, K.L., Griffiths, S.W., McKelvey, S., and Armstrong, J.D. 2010. Deposition of Atlantic 658 salmon Salmo salar carcasses in a Scottish upland catchment. J. Fish Biol. 77(4): 927659934.

660 Wipfli, M.S., Hudson, J.P., Caouette, J.P., and Chaloner, D.T. 2003. Marine subsidies in 661 662 663 664 665 $666 \quad$ Jersey. freshwater ecosystems: salmon carcasses increase the growth rates of stream-resident salmonids. Trans. Am. Fish. Soc. 132(2): 371-381.

Yang, L.H., Edwards, K.F., Byrnes, J.E., Bastow, J.L., Wright, A.N., and Spence, K.O. 2010. A meta-analysis of resource pulse-consumer interactions. Ecol. Monogr. 80(1): 125-151.

Zar, J.H. 1999. Biostatistical analysis. 4th edition. Prentice-Hall, Upper Saddle River, New

667 Zhang, Y., and Richardson, J.S. 2011. Contrasting effects of cross-ecosystem subsidies and 668 predation on benthic invertebrates in two Pacific coastal streams. Aquat. Sci. 73(1): 53669 62.

670 
671 Table 1. Stream width and mean $( \pm \mathrm{SE})$ total depth and water velocity along cross-sectional

672 transects at each site and mean $( \pm \mathrm{SE})$ percent overstory density among three nutrient diffusing

673 substrate arrays placed at each site at base flow prior to the addition of sea lamprey carcasses.

674

\begin{tabular}{lcccc}
\hline Site & $\begin{array}{c}\text { Stream } \\
\text { width }(\mathrm{m})\end{array}$ & $\begin{array}{c}\text { Average } \\
\text { depth }(\mathrm{m})\end{array}$ & $\begin{array}{c}\text { Average } \\
\text { velocity }\left(\mathrm{ms}^{-1}\right)\end{array}$ & $\begin{array}{c}\text { Overstory } \\
\text { density }(\%)\end{array}$ \\
\hline 1 & 7.5 & $0.20(0.01)$ & $0.35(0.15)$ & $77.8(9.2)$ \\
2 & 8.0 & $0.20(0.02)$ & $0.27(0.07)$ & $67.1(8.7)$ \\
3 & 7.2 & $0.23(0.06)$ & $0.30(0.10)$ & $83.7(0.7)$ \\
4 & 5.3 & $0.23(0.02)$ & $0.46(0.10)$ & $87.5(0.6)$ \\
5 & 4.8 & $0.23(0.04)$ & $0.34(0.09)$ & $94.1(0.9)$ \\
6 & 6.6 & $0.27(0.03)$ & $0.23(0.02)$ & $92.7(2.4)$ \\
7 & 7.9 & $0.22(0.01)$ & $0.38(0.14)$ & $75.0(8.8)$ \\
8 & 6.8 & $0.24(0.07)$ & $0.33(0.03)$ & $66.7(5.2)$ \\
9 & 7.8 & $0.24(0.03)$ & $0.21(0.04)$ & $91.0(1.5)$ \\
10 & 5.4 & $0.21(0.03)$ & $0.35(0.13)$ & $72.6(5.0)$ \\
\hline Average & 6.7 & 0.23 & 0.32 & 80.8 \\
\hline
\end{tabular}


675 Table 2. Pillai's trace, $F$, and $P$ statistics from MANOVA results for macroinvertebrate taxa and

$676 P$. marinus ammocoetes treating $\delta^{15} \mathrm{~N}$ and $\delta^{13} \mathrm{C}$ as dependent variables in the model. Bolded

677 values indicate significant main effects or interactions at $p<0.05$.

\begin{tabular}{|c|c|c|c|c|}
\hline & Pillai's trace & d.f. & $F$ & $P$ \\
\hline \multicolumn{5}{|l|}{ Heptageniidae } \\
\hline Time & 1.256 & 4,60 & 25.3 & $<0.001$ \\
\hline Site & 0.551 & 4,60 & 5.7 & $<0.001$ \\
\hline Interaction & 0.730 & 8,60 & 4.3 & $<0.001$ \\
\hline \multicolumn{5}{|c|}{ Hydropsychidae } \\
\hline Time & 0.766 & 4,60 & 9.3 & $<0.001$ \\
\hline Site & 0.407 & 4,60 & 3.8 & 0.007 \\
\hline Interaction & 0.138 & 8,60 & 0.6 & 0.810 \\
\hline \multicolumn{5}{|c|}{ Philopotamidae } \\
\hline Time & 0.968 & 4,58 & 13.6 & $<0.001$ \\
\hline Site & 0.134 & 4,58 & 1.0 & 0.394 \\
\hline Interaction & 0.289 & 8,58 & 1.2 & 0.301 \\
\hline \multicolumn{5}{|l|}{ Perlidae } \\
\hline Time & 0.716 & 4,58 & 8.1 & $<0.001$ \\
\hline Site & 0.410 & 4,58 & 3.7 & 0.009 \\
\hline Interaction & 0.233 & 8,58 & 1.0 & 0.478 \\
\hline \multicolumn{5}{|l|}{ Corydalidae } \\
\hline Time & 0.172 & 4,50 & 1.2 & 0.332 \\
\hline Site & 0.105 & 4,50 & 0.7 & 0.601 \\
\hline Interaction & 0.108 & 8,50 & 0.4 & 0.939 \\
\hline \multicolumn{5}{|l|}{ E. complanata } \\
\hline Time & 0.847 & 4,64 & 11.8 & $<0.001$ \\
\hline Site & 0.087 & 2,31 & 1.5 & 0.244 \\
\hline Interaction & 0.053 & 4,64 & 0.4 & 0.782 \\
\hline \multicolumn{5}{|l|}{ P. marinus } \\
\hline Time & 0.100 & 2,19 & 1.1 & 0.368 \\
\hline Site & 0.198 & 2,19 & 2.4 & 0.122 \\
\hline Interaction & 0.180 & 2,19 & 2.1 & 0.152 \\
\hline
\end{tabular}




\section{$679 \quad$ Figure captions}

680

681 Figure 1. Location of study reaches for experimental sea lamprey carcass addition during 2013

682 (A), and 2014 (B) on Sedgeunkedunk Stream, Maine. Circles indicate former or current

683 obstacles to fish passage. Inset depicts locations of ten sites within the experimental reach

684 during 2014. Shaded boxes indicate sites that received additions of sea lamprey carcasses. Map

685 source data were obtained from the United States Department of Agriculture Geospatial Data

686 Gateway.

687

688

Figure 2. Mean $( \pm \mathrm{SE})$ chlorophyll $a$ concentrations from nutrient diffusing substrates among

689 four nutrient treatments over a three week period upstream and downstream of sea lamprey

690 carcass addition in Sedgeunkedunk Stream, Maine, 2013. $F$ and $P$ statistics are presented for a

691 model testing for the effects of reach, week, and nutrient treatment (see text for explanation).

692

693 Figure 3. Mean ( \pm SE) ammonium (a), nitrate (b), and total soluble phosphorus (c) stream water

694 concentrations over a two week period among the average of the upstream reference sites $(1,2)$,

695 two mid-reach sites $(5,6)$, and the two lower most downstream sites $(9,10$; left panels), and

696 during days 2-4 among all sites (right panels) following sea lamprey carcass addition in

697 Sedgeunkedunk Stream, Maine, 2014. Time zero indicates samples taken before the addition of

698 carcasses. The y-axis scales differ among nutrients. $F$ and $P$ statistics are presented for a multi-

699 factor ANOVA model testing for the effects of site and day (see text and Figure 1 for site

700 locations and descriptions).

701 
702 Figure 4. Mean ( \pm SE) chlorophyll $a$ concentrations following sea lamprey carcass addition 703 among sites downstream of carcasses adjusted for average chlorophyll $a$ concentrations from 704 upstream reference sites from nutrient diffusing substrates among four nutrient treatments over 705 three weeks $(\mathrm{a}-\mathrm{c})$ in Sedgeunkedunk Stream, Maine, 2014. $F$ and $P$ statistics are presented for a 706 multi-factor ANOVA model testing for the effects of site, week, and nutrient treatment (see text 707 and Figure 1 for site locations and descriptions).

708

709 Figure 5. Mean $( \pm \mathrm{SE}) \delta^{15} \mathrm{~N}$ and $\delta^{13} \mathrm{C}$ isotope values among six macroinvertebrate taxa and $P$. 710 marinus ammocoetes before carcass addition (white), and at weeks 3 (gray) and 7 (black) after 711 carcass addition on Sedgeunkedunk Stream, Maine, 2014. The triangle symbol corresponds to 712 site 2 (reference), the circle to site 5 (mid-reach), and the square to site 9 (downstream). The 713 hexagon in the upper right hand corner of each plot is the stable isotope signature of adult sea

714 lamprey carcasses used in this experiment (mean $\pm \mathrm{SE} \delta^{15} \mathrm{~N}=12.16 \pm 0.22 ; \delta^{13} \mathrm{C}=-17.96 \pm$ 715 0.19). The $x$ - and y-axis scales differ among taxa. 


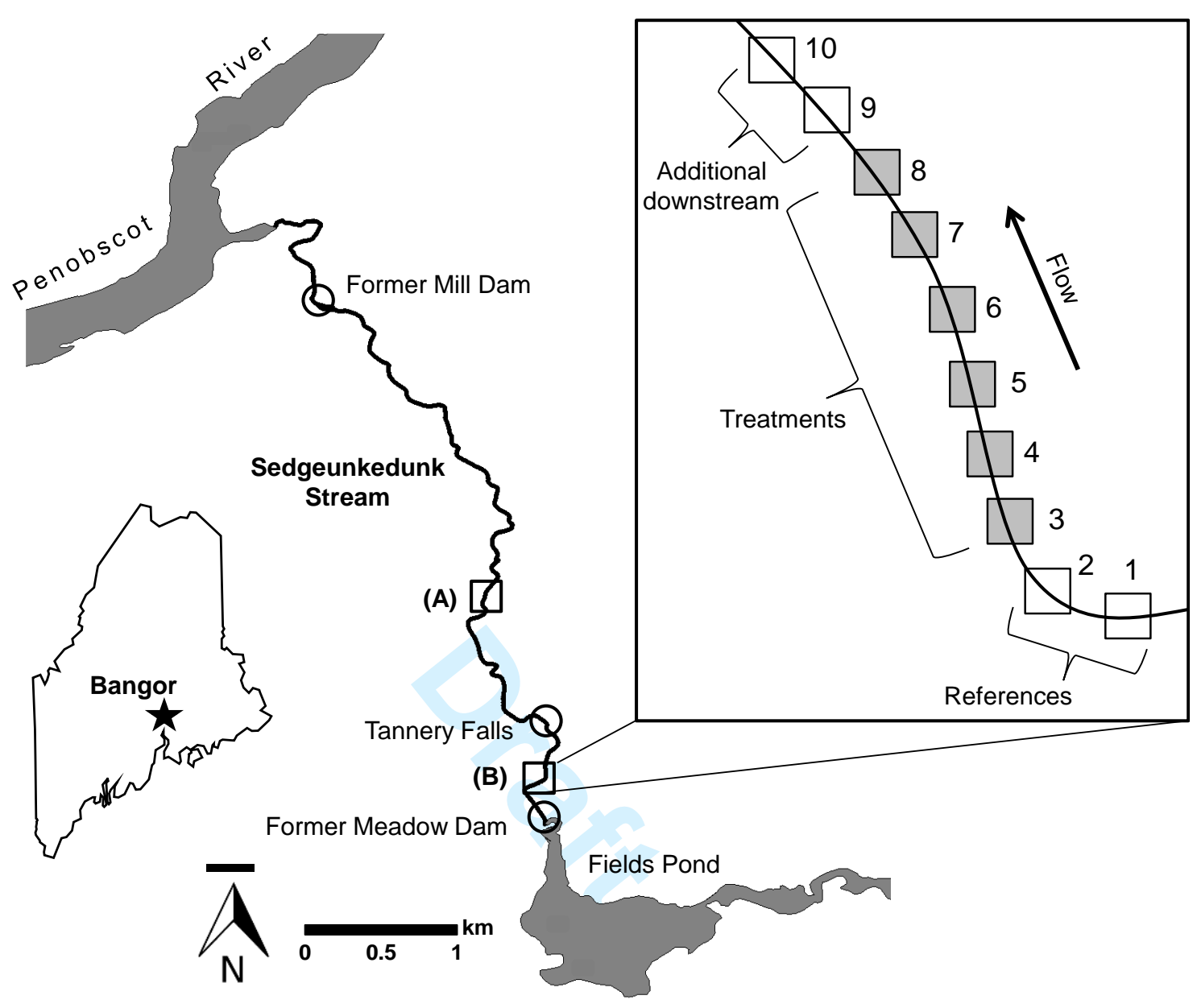

Figure 1. 


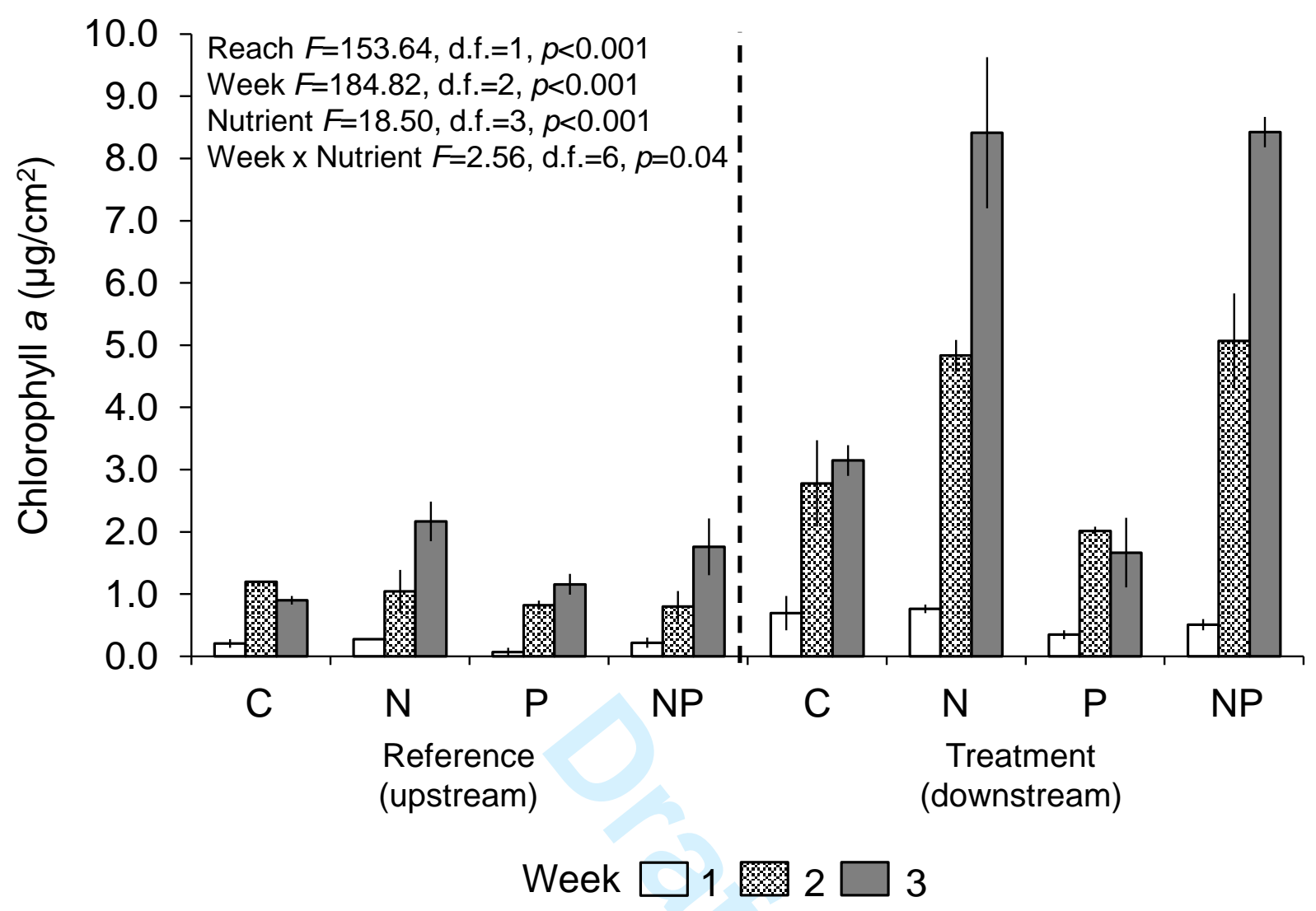

Figure 2. 

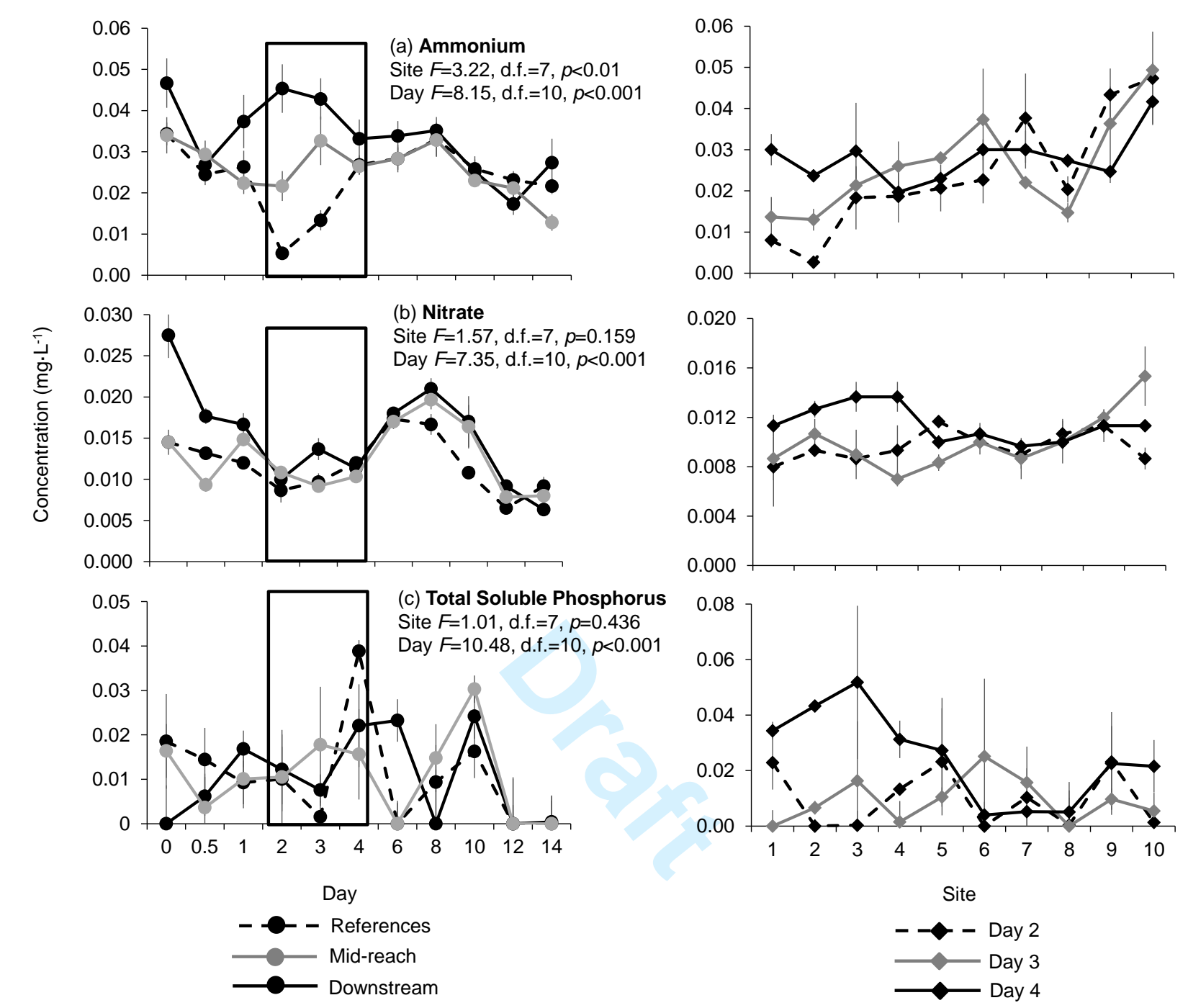


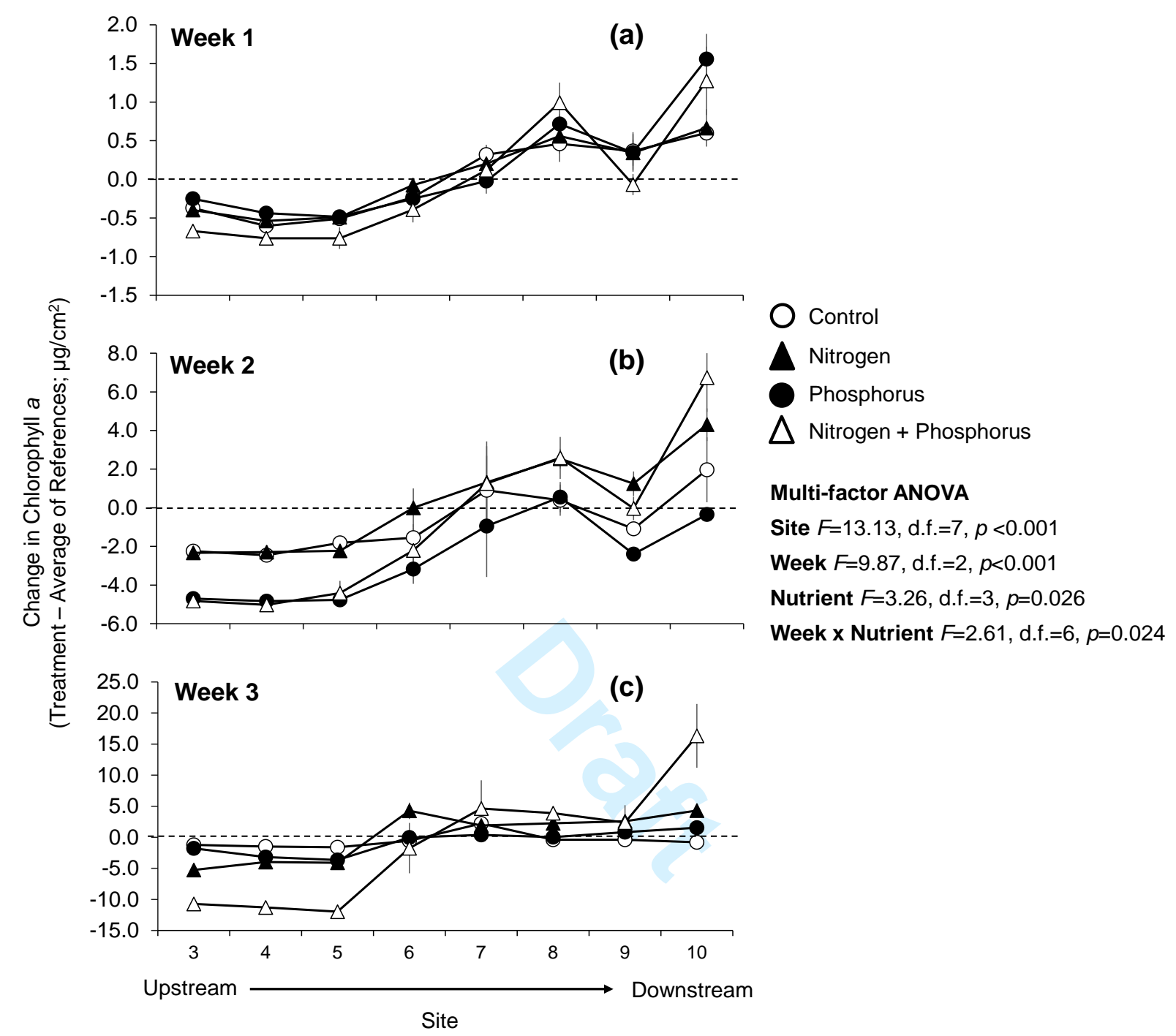

Figure 4. 

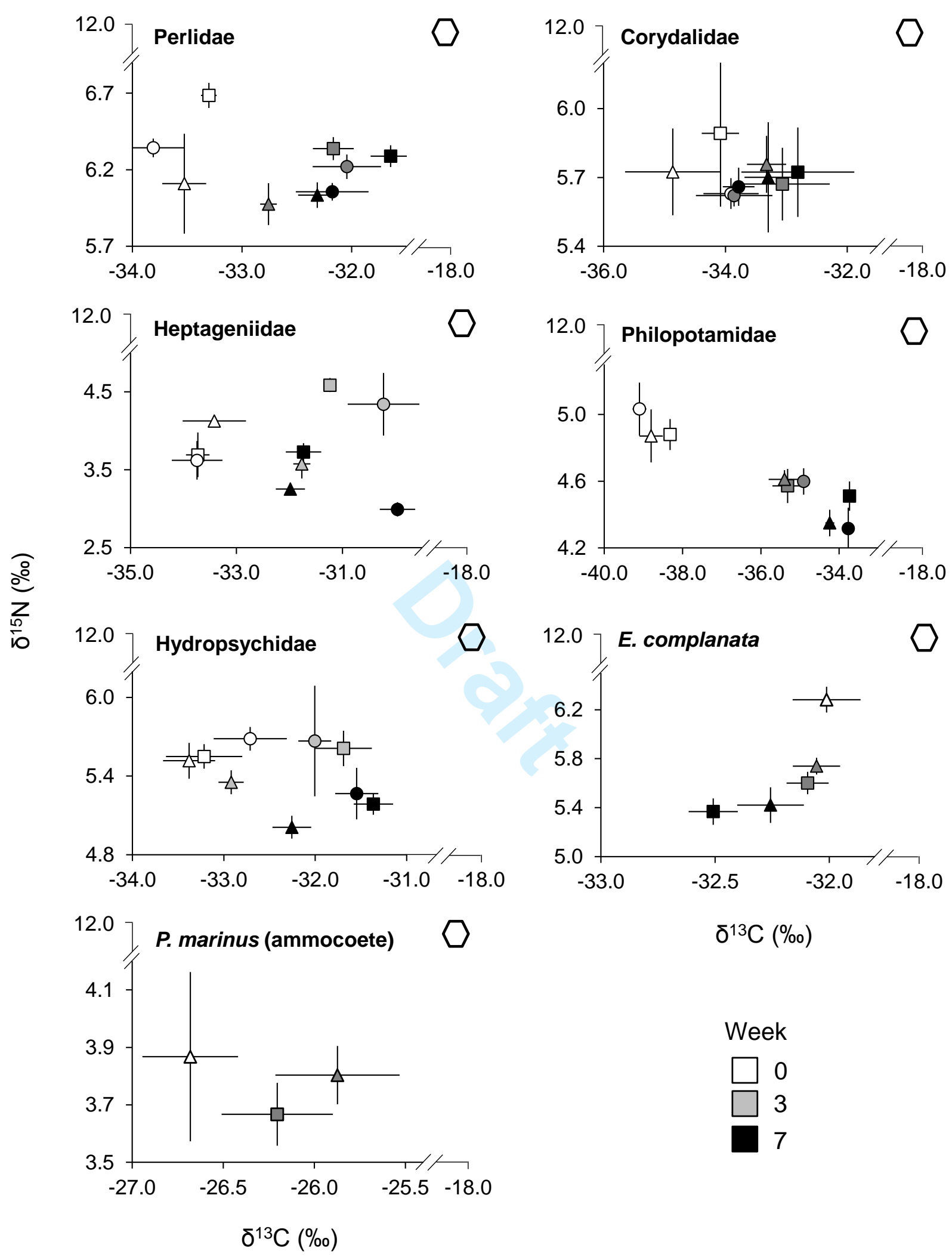

Figure 5. 